\title{
Chromosomes and Nuclear DNA in Regenerants of Scilla indica (Roxb.) Baker Derived from Two Explant Sources
}

\author{
Bipasha Chakravarty and Sumitra Sen
}

Centre of Advanced Study, (Cell and Chromosome Research) Department of Botany, University of Calcutta, 35, Ballygunge Circular Road, Calcutta 700019, India

Accepted September 12, 1991

The use of tissue culture techniques is often employed to generate genetic variability at the somatic cell level (Larkin and Scowcroft 1981, Jha and Sen 1987). The plants regenerating through in vitro culture may (Mc. Coy et al. 1982, Karp and Maddock 1984) or may not necessarily exhibit cytogenetic variability (Heysers and Nabors 1982, Hanna et al. 1984, Sengupta et al. 1988). In general, plants regenerating via somatic embryogenesis have been reported to be euploid and free of any noticeable morphological variability (Swedlund and Vasil 1985). Embryogenic cultures as well as the plants derived from them are in most cases cytogenetically normal and stable (Vasil 1982).

Scilla indica (Roxb.) Baker of the family Liliaceae is cultivated in India for its high content of sterols and cardiac glycosides. The occurrence of chromosomal instability during in vitro growth has been studied previously in this species (Chakraborty and Sen 1983) and regeneration through both organogenesis and somatic embryogenesis have been reported earlier (Chakravarty and Sen 1987, 1989).

The present study reports the results on chromosomal study of regenerated plantlets of Scilla indica derived from two pathways namely organogenesis and somatic embryogenesis from leaf and anther callus respectively. The study of in situ DNA content of the regenerated plantlets was also included within the scope of investigation to note the nuclear DNA variation, if any, occurring in both the pathways due to differential DNA amplification.

\section{Materials and methods}

Bulbs of Scilla indica (Roxb.) Baker were collected from western coastal belts of India and replanted in experimental plots. Young leaf-tips and anthers of unopened flower buds were taken as explants. These were sterilized with $0.1 \%$ mercuric chloride for fifteen minutes followed by several washings in sterile distilled water. Buds were opened in aseptic conditions, anthers removed with a sterile needle and placed in the culture medium. For callus cultures, the basal medium of Murashige and Skoog (1962) (MS) was used with an addition of $2 \mathrm{mg} / \mathrm{l}$ 2, 4-D (Dichloro-phenoxyacetic acid) and 15\% (V/V) coconut milk (filter-sterilized). $\mathrm{pH}$ of the medium was adjusted to 5.6, solidified with $0.6 \%$ agar-agar (bacteriological grade) and cultures incubated at a temperature of $25^{\circ} \mathrm{C}$ and $55 \%$ relative humidity for a $16 / 8$ hours light/ dark photoperiod.

For regeneration of plants from callus via organogenesis and somatic embryogenesis, the calli were transferred to media containing $2 \mathrm{mg} / 1$ Napthalene acetic acid and $15 \%$ coconut milk (Chakravarty and Sen 1987, 1989). Regenerated plantlets were transferred to MS medium with half concentration of salts for rooting.

For cytological study, root-tips of regenerated plantlets were treated with saturated solution of paradichlorobenzene and $0.002 \mathrm{M}$ hydroxyquinolene (in 2:1 proportion) for three and half hours, followed by overnight fixation in acetic ethanol $(1: 3)$ and staining with aceto- 
orcein (Sharma and Sharma 1980).

For in situ estimation of nuclear DNA, root-tips were hydrolyzed in $(\mathrm{N}) \mathrm{HCl}$ and stained in Feulgen's reagent. Squashes were prepared and readings of transmittance values for the Feulgen-stained nuclei were measured with Leitz-Wetzlar Aristophot with microspectrophotometer in a wavelength of $550 \mathrm{~nm}$ (Sharma and Sharma 1980). 4C value was calculated on the basis of optical density in terms of relative arbitrary units of absorbances which were converted to absolute units in picograms by using 4C nuclear DNA value for Allium cepa roottips as standard (Van't Hof 1965).

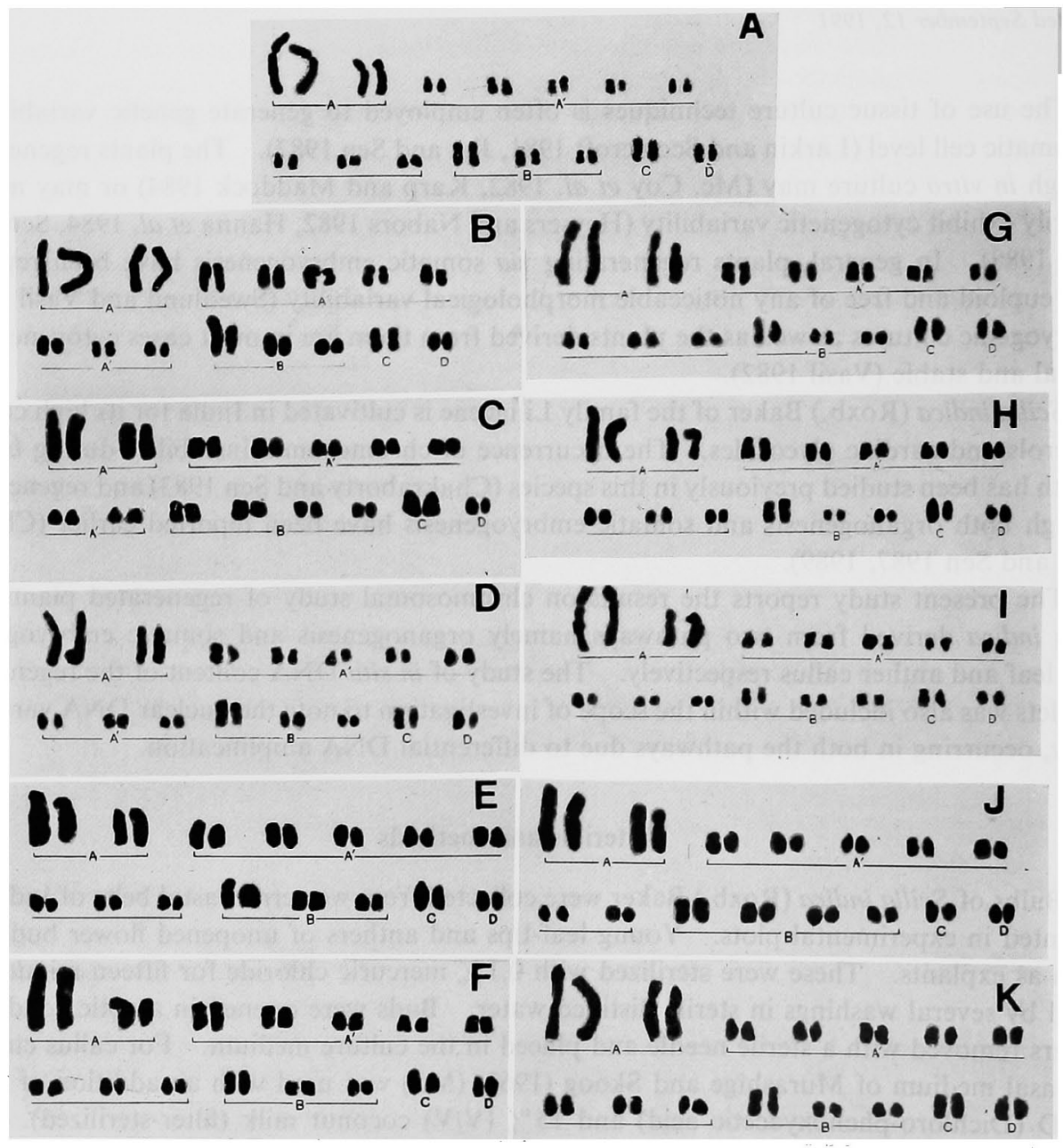

Fig. 1. Karyotype of plants showing the different types of chromosomes. A, Karyotype of in vivo plant, B-F, of regenerants from leaf callus. G-K, of regenerants from anther callus.

Results

Cytological investigations of root-tips of plants regenerating from leaf-derived callus through organogenesis showed that all the forty regenerated plantlets analyzed were diploids containing $2 \mathrm{n}=30$ chromosomes. These included plants regenerating from callus of different ages i. e. 60 day old to 240 day old callus. Calli that were over 240 days old did not show any regeneration. 
Out of these forty regenerated plantlets, five plants were studied in detail for karyotype analysis. A comparison of the karyotype of root-tips of in vitro grown plantlets with those of an in vivo grown plant (Fig. 1) showed that all chromosomes could be grouped into five types-A, A $, B, C$ and $D$ on the basis of the position of primary and secondary constrictions and length (Table 1).

Of the five regenerated plantlets from leaf callus analyzed for chromosome details, four plants were found to be similar in gross karyotypic features with those of the in vivo grown plant (Fig. 1) i.e. two pairs of chromosomes of type A, eight pairs of type $\mathrm{A}^{\prime}$, three pairs of type $B$ and two pairs each of types C and D (Table 2). But in case of plant no. 2 (Fig. IC) differences from the in vivo plant were noted in the number of chromosomes of type $\mathrm{A}^{\prime}$ and $\mathrm{B}$ (Table 2). Among members of homologous pairs, slight size differences in the length of chromosomes were also noted in some cases as in plants 2, 3 and 4.

Table 1. Characteristics of different chromosome types found in Scilla indica

\begin{tabular}{ccccc}
\hline Type & $\begin{array}{c}\text { Number of } \\
\text { constrictions }\end{array}$ & $\begin{array}{c}\text { Nature of primary } \\
\text { constriction }\end{array}$ & $\begin{array}{c}\text { Nature of secondary } \\
\text { constriction }\end{array}$ & $\begin{array}{c}\text { Range of length of } \\
\text { chromosome } \\
(\mu \mathrm{m})\end{array}$ \\
\hline A & One & Submedian & - & $13-5$ \\
A $^{\prime}$ & One & Submedian & - & $4.9-1.3$ \\
B & One & Median & Subterminal & $5-1.5$ \\
C & Two & Submedian & Subterminal & $3-2$ \\
D & Two & Subterminal & & $3-2$ \\
\hline
\end{tabular}

Table 2. Karyotype analysis of regenerated diploid plants derived from callus of two explants

\begin{tabular}{|c|c|c|c|}
\hline $\begin{array}{l}\text { Plant } \\
\text { no. }\end{array}$ & Source of plant & Karyotype formula & $\begin{array}{l}\text { Range of chromosome length } \\
\qquad(\mu \mathrm{m})\end{array}$ \\
\hline- & In vivo plant & $4 A+16 A^{\prime}+6 B+2 C+2 D$ & $10.5-1.5$ \\
\hline 1 & $\begin{array}{l}\text { In vitro plant } \\
\text { from leaf callus }\end{array}$ & $4 A+16 A^{\prime}+6 B+2 C+2 D$ & $10.0-1.5$ \\
\hline 2 & $"$ & $4 \mathrm{~A}+14 \mathrm{~A}^{\prime}+8 \mathrm{~B}+2 \mathrm{C}+2 \mathrm{D}$ & $9.5-1.5$ \\
\hline 3 & $" \prime$ & $4 A+16 A^{\prime}+6 B+2 C+2 D$ & $9.5-1.5$ \\
\hline 4 & $" \prime$ & $4 A+16 A^{\prime}+6 B+2 C+2 D$ & $13.0-1.5$ \\
\hline 5 & $"$ & $4 A+16 A^{\prime}+6 B+2 C+2 D$ & $10.0-1.5$ \\
\hline 6 & $\begin{array}{l}\text { In vitro plant } \\
\text { from anther callus }\end{array}$ & $4 A+16 A^{\prime}+6 B+2 C+2 D$ & $11.5-1.5$ \\
\hline 7 & "f & $4 A+16 A^{\prime}+6 B+2 C+2 D$ & $12.0-1.25$ \\
\hline 8 & $" 1$ & $4 \mathrm{~A}+16 \mathrm{~A}^{\prime}+6 \mathrm{~B}+2 \mathrm{C}+2 \mathrm{D}$ & $10.0-1.5$ \\
\hline 9 & " & $4 A+14 A^{\prime}+8 B+2 C+2 D$ & $10.0-1.5$ \\
\hline 10 & " & $4 A+16 A^{\prime}+6 B+2 C+2 D$ & $9.5-1.5$ \\
\hline
\end{tabular}

The plants regenerated from anther callus via somatic embryogenesis showed both diploid and mixoploid types. Out of twenty plants analyzed, seventeen plants were observed to be diploids with all the cells showing $2 n=30$ chromosomes, whereas three plants had a mixed population of cells comprising of diploids, hypodiploids and hyperdiploids.

Detailed karyotype analysis of five diploid plantlets regenerated from anther callus (Table 2) showed that in plantlets $6,7,8$ and 10 no differences in the morphology of the chromosomes were observed from the in vivo grown plant (Fig. 1). But only in case of plant no. 9 (Fig. 1J) changes in the number of chromosomes of types $A^{\prime}$ and $B$ were noted (Table 2).

The mixoploid plantlets obtained from anther callus had predominantly diploid cells but some hypodiploids and hyperdiploid cells were also seen in low proportions (Table 3) the precentage of which differed in the three plants. Mitotic abnormalities were also noted in these 
mixoploid plants. The karyotype of the diploid cells was similar to those of in vivo grown plants.

\section{DNA content of regenerants}

Estimation of the DNA content of regenerants derived from leaf callus showed that all the forty diploid plantlets analyzed had a mean DNA value of 22.6 picograms which resembled

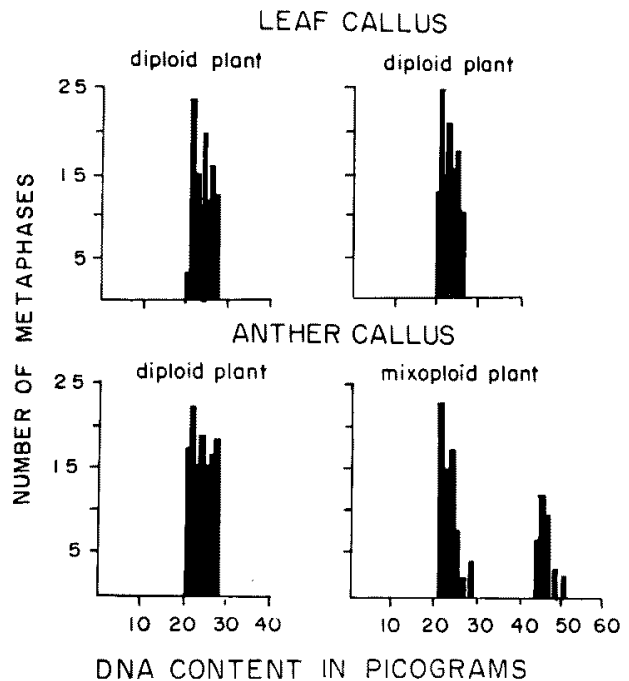

Fig. 2. DNA distribution pattern of regenerants from leaf and anther callus.

Table 3. Cytological status of mixoploid plants regenerated from anther callus

\begin{tabular}{|c|c|c|c|c|c|}
\hline \multirow{2}{*}{$\begin{array}{l}\text { Plant } \\
\text { no. }\end{array}$} & \multirow[b]{2}{*}{ Mitotic Index } & \multicolumn{3}{|c|}{ Percentage of cells showing } & \multirow{2}{*}{$\begin{array}{c}\text { Mitotic } \\
\text { abnormalities }\end{array}$} \\
\hline & & $\begin{array}{l}\text { Diploids } \\
2 n=30\end{array}$ & $\begin{array}{l}\text { Hypodiploids } \\
2 \mathrm{n}=30\end{array}$ & $\begin{array}{c}\text { Hyperdiploids } \\
2 n=30\end{array}$ & \\
\hline 1 & 2.81 & 88.68 & 5.3 & 6.02 & 34.1 \\
\hline 2 & 3.96 & 88.10 & 1.8 & 10.10 & 25.2 \\
\hline 3 & 2.57 & 93.03 & 2.62 & 4.35 & 28.7 \\
\hline
\end{tabular}

Table 4. Mean DNA content of regenerated plantlets derived from leaf and anther callus

\begin{tabular}{lccc}
\hline Source of plant & $\begin{array}{c}\text { Cytological status } \\
\text { of plant }\end{array}$ & $\begin{array}{c}\text { No. of plants } \\
\text { analyzed }\end{array}$ & $\begin{array}{c}\text { Mean DNA content in picograms } \\
\pm \text { standard error }\end{array}$ \\
\hline In vivo plant & Diploid & 5 & $23.4 \pm 0.12$ \\
Leaf callus & Diploid & 40 & $22.6 \pm 0.17$ \\
Anther callus & Diploid & 17 & $21.9 \pm 0.56$ \\
Anther callus & Mixoploid & 3 & $34.2 \pm 1.21$ \\
\hline
\end{tabular}

that of in vivo plant (Table 4). The DNA content of these diploid plants was distributed at only one peak corresponding to the 4C DNA content value (Fig. 2) and no great differences were observed in the DNA distribution pattern of all diploid plants examined.

In plants regenerating from anther callus, the diploid plantlets showed a mean DNA value of 21.9 picograms which resembled those of in vivo grown plants (Table 4). On the other 
hand in the three plants with mixoploid population of cells, the mean DNA content showed a value of 34.2 picograms (Table 4) which indicated the presence of cells at various ploidy levels. In mixoploid plants, the DNA content showed various values distributed in different peaks (Fig. 2) whereas the diploid plants had DNA values concentrated at one peak only corresponding to the $4 \mathrm{C}$ DNA level.

\section{Discussion}

The predominance of diploid cells in regenerants from both organogenetic and embryogenetic pathways clearly indicates that diploid cells in the callus get preferentially selected for regeneration (Orton 1980, Ogihara 1981). In regenerants derived from anther callus through somatic embryogenesis, a few mixoploid plants were also obtained. Thus, the possibility of securing stable diploid genotypes is higher from leaf callus via organogenesis rather than from anther callus through somatic embryogenesis in Scilla indiva. Stable regenerants from somatic embryos have, however been reported in other species (Lu and Vasil 1982, Hanna et al. 1984).

Detailed karyotype analysis of chromosomes of regenerated diploid plants revealed apparently minute changes in the chromosome morphology in plants regenerating from both pathways. To what extent this is a reflection of chromosomal differences or slight differential condensation in the metaphases is yet to be ascertained. Since the changes are very small and almost imperceptible it is inferred that karyotypes of regenerated diploid plants do not differ, at least in gross features.

In the mixoploid plants, the number of hyperdiploid cells are more than in the hypodiploids (Table 3). If their origin is through non-disjunction, the ratio of the two should have been the same, as non-disjunction results in equal number of hypo- and hyperdiploid nuclei. The low frequency of hypodiploid cells may suggest their selective elimination in mitosis.

The DNA content showed a wide variation in the mixoploid plants with different peaks, one near the tetraploid value having high amounts of mean nuclear DNA. This mixoploidy and high DNA may owe their origin to the variability in anther callus (Mc. Coy et al. 1982, Armstrong et al. 1983) and ultimately to low mosaicism in the explant. The nature of the explant thus plays an important role in the generation of the variability as noted in other species as well (Cavallini and Cionini 1986).

The heterogeneity of anther tissue including the presence of tapetal cells may contribute to variation in chromosome and DNA amounts. The presence of cells at different ploidy levels in the anther tissue at the time of explantation might have been reflected in the regenerants. Thus anther culture, at least in Scilla indica, may provide scope to broaden the genetic spectrum and induce a wide genetic base with numerical if not structural variations of chromosomes.

In this species, leaf explants can be utilized to secure mass propagation of stable regenerants whereas anther callus offers scope for securing mixoploid regenerants and variant genotypes.

\section{Summary}

Chromosome analysis of regenerants of Scilla indica (Roxb.) Baker obtained through organogenesis from leaf callus and somatic embryogenesis from anther callus was carried out. The plants regenerating from the leaf callus were all diploids whereas those regenerating through somatic embryos from anther cellus showed both diploid and mixoploid plantlets. The karyotype of the regenerants did reveal major structural changes in the diploid plantlets derived from both callus lines. In situ nuclear DNA estimation of the regenerants indicated 
incerase in mean DNA value only in case of a few mixoploid plantlets regenerated from anther callus via somatic embryogenesis. The nuclear state of the explant thus has an important role to play in determining the cytological status of regenerants.

\section{Acknowledgements}

The authors wish to thank Prof. A. K. Sharma, for his suggestions and the first author is grateful to the CSIR, New Delhi for financial assistance.

\section{References}

Armstrong, K. C., Nakamura, C. and Keller, W. A. 1983. Karyotype instability in tissue culture regenerants of Triticale (Triticosecale wiltmack) cv. 'Walsh' from 6-month old callus culture. Z. Pflanzenzucht. 91: $233-245$.

Cavallini, A. and Cionini, P. G. 1986. Nuclear DNA content in differentiated tissues of sunflower (Helianthus annuus L.). Protoplasma 130: 91-97.

Chakraborty, S. P. and Sen, S. 1983. Chromosomal changes in the scale leaf callus of diploid S. indica. Proc. Ind. natn. Sci. Acad. B-49(2): 120-124.

Chakravarty, B. and Sen, S. 1987. In vitro regeneration from callus cultures of Scilla indica (Roxb.) Baker. Curr. Sci. 56(9): 960-962.

- and - 1989. Regeneration through somatic embryogenesis from anther explants of Scilla indica (Roxb.) Baker. Plant Cell Tissue and Organ Culture. 19: 71-75.

Hanna, W. W., Lu, C. Y. and Vasil, I. K. 1984. Uniformity of plants regenerating from somatic embryos of Panicum maximum Jacq. (guinea grass). Theor. Appl. Genet. 67: 155-159.

Heysers, J. W. and Nabors, M. W. 1982. Regeneration of Prosco millet from embryogenic calli derived from various plant parts. Crop Sci. 22: 1070-1074.

Jha, S. and Sen, S. 1987. Karyotype variability in regenerated plants of Urginea indica Kunth. Cytologia 52: $615-626$.

Karp, A. and Maddock, S. E. 1984. Chromosome variation in wheat plants regenerating from cultured immature embryos. Theor. Appl. Genet. 67: 249-255.

Larkin, P. J. and Scowcroft, W. R. 1981. Somaclonal variation-A novel source of variability from cell cultures for plant improvement. Theor. Appl. Genet. 60: 197-214.

Lu, C. and Vasil, I. K. 1982. Somatic embryogenesis and plant regeneration in tissue cultures of Panicum maximum Jacq. Amer. J. Bot. 69: 77-81.

Mc. Coy, T. J., Philips, R. L. and Rines, H. W. 1982. Cytogenetic analysis of plants regenerating from oat (Avena sativa) tissue cultures, high frequency of partial chromosome loss. Can. J. Genet. Cytol. 24: $37-50$.

Murashige, T. and Skoog, F. 1962. A revised medium for rapid growth and bioassays with tobacco tissue cultures. Physiol. Plant. 15: 473-497.

Ogihara, Y. 1981. Tissue culture in Haworthia IV. Genetic characterization of plants regenerating from callus. Theor. Appl. Genet. 60: 353-363.

Orton, T. J. 1980. Chromosome variability in tissue cultures and regenerated plantlets of Hordeum. Theor. Appl. Genet. 56:

Sengupta, J., Jha, S. and Sen, S. 1988. Karyotype stability in long-term callus derived plants of Crepis tectorum L. Biol. Plant (Praha) 30(4): 247-251.

Sharma, A. K. and Sharma, A. 1980. In: Chromosome Techniques-Theory and Practice. 3rd Ed. London, Butterworths.

Swedlund, B. and Vasil, I. K. 1985. Cytogenetic characterization of embryogenic callus and regenerated plants of Pennisetum americanum (L.) K. Schum. Theor. Appl. Genet. 69: 575-581.

Van't Hof, J. 1965. Relationship between mitotic cycle duration, S period duration and the average rate of DNA synthesis in the root meristem cells of several plants. Exp. Cell Res. 39: 48-58.

Vasil, I. K. 1982. Somatic embryogenesis and plant regeneration in cereals and grasses. In: Plant Tissue Culture (Fujiwara A. Ed.) Proc. 5th Intl. Cong. Pl. Tissue and Cell Culture: 101-102. 